\title{
Testing methods to mitigate Caribbean yellow-band disease on Orbicella faveolata
}

Carly J. Randall Corresp., ${ }^{1,2}$, Elizabeth M. Whitcher ${ }^{1}$, Tessa Code ${ }^{3}$, Clayton Pollock ${ }^{3}$, Ian Lundgren ${ }^{3}$, Zandy Hillis-Starr ${ }^{3}$, Erinn M. Muller ${ }^{\text {Corresp. } 4}$

\footnotetext{
1 Florida Institute of Technology, Melbourne, Florida, United States

2 Australian Institute of Marine Science, Townsville, Queensland, Australia

3 National Park Service, St. Croix, United States

4 Mote Marine Laboratory, Sarasota, Florida, United States

Corresponding Authors: Carly J. Randall, Erinn M. Muller

Email address: crandall2012@my.fit.edu, emuller@mote.org
}

Outbreaks of coral diseases continue to reduce global coral populations. In the Caribbean, yellow band is a severe and wide-spread disease that commonly affects corals of the Orbicella spp. complex, significantly impeding coral reproduction, and hindering the natural recovery of Orbicella spp. populations. Caribbean yellow-band disease (CYBD) lesions may be severe, and often result in the complete loss of coral tissue. The slow spread of CYBD, however, provides an opportunity to test methods to mitigate the disease. Here we report the results of in situ experiments, conducted within Buck Island Reef National Monument in St. Croix, USVI, to test the effectiveness of three techniques to minimize disease impact on $O$. faveolata: (1) shading, (2) aspirating, and (3) chiseling a 'firebreak' to isolate the lesion. Neither shading nor aspirating the diseased tissue significantly reduced CYBD tissue loss. However, chiseling reduced the rate and amount of tissue lost by $31 \%$. While $30-40 \%$ of the chiseled lesions appeared to be free of disease signs 12-16 months after treatment, success significantly and steadily declined over 23 months, indicating a possible lack of long-term viability of the technique. The results of this study demonstrate that creating a 'firebreak' between diseased and healthy-appearing tissue slows the spread of the disease and may prolong the life of $O$. faveolata colonies. The firebreak method yielded the best results of all the techniques tested, and also required the least amount of effort and resources. However, we do not recommend that this treatment alone be used for long-term disease mitigation. Rather, we propose that modifications of this and other treatment options be sought. The results also highlight the need for extended monitoring of CYBD after any treatment, due to the slow but variable rate and pattern of tissue loss in this disease. 
1

2

3

4

5

6

7

8

9

10

11

12

13

14

15

16

17 *Corresponding authors: crandal12012@my.fit.edu (C.J.R.) and emuller@mote.org (E.M.M.)

\section{Testing methods to mitigate Caribbean yellow-band disease on Orbicella \\ faveolata}

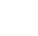

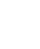

Carly J. Randall ${ }^{1 \phi^{*}}$

Elizabeth M. Whitcher ${ }^{1}$

Tessa Code ${ }^{3}$

Clayton Pollock ${ }^{3}$

Ian Lundgren ${ }^{3}$

Zandy Hillis-Starr ${ }^{3}$

Erinn M. Muller ${ }^{2 *}$

${ }^{1}$ Florida Institute of Technology, Melbourne, FL, USA

${ }^{2}$ Mote Marine Laboratory, Sarasota FL, USA

${ }^{3}$ National Park Service, St. Croix, VI, USA

${ }^{\phi}$ Current Address: Australian Institute of Marine Science, Queensland, Australia

18

19 


\section{Abstract}

Outbreaks of coral diseases continue to reduce global coral populations. In the Caribbean,

22 yellow band is a severe and wide-spread disease that commonly affects corals of the Orbicella

23 spp. complex, significantly impeding coral reproduction, and hindering the natural recovery of

Orbicella spp. populations. Caribbean yellow-band disease (CYBD) lesions may be severe, and often result in the complete loss of coral tissue. The slow spread of CYBD, however, provides an opportunity to test methods to mitigate the disease. Here we report the results of in situ experiments, conducted within Buck Island Reef National Monument in St. Croix, USVI, to test the effectiveness of three techniques to minimize disease impact on O. faveolata: (1) shading, (2) aspirating, and (3) chiseling a 'firebreak' to isolate the lesion. Neither shading nor aspirating the diseased tissue significantly reduced CYBD tissue loss. However, chiseling reduced the rate and amount of tissue lost by $31 \%$. While $30-40 \%$ of the chiseled lesions appeared to be free of disease signs 12-16 months after treatment, success significantly and steadily declined over 23 months, indicating a possible lack of long-term viability of the technique. The results of this study demonstrate that creating a 'firebreak' between diseased and healthy-appearing tissue slows the spread of the disease and may prolong the life of $O$. faveolata colonies. The firebreak method yielded the best results of all the techniques tested, and also required the least amount of effort and resources. However, we do not recommend that this treatment alone be used for longterm disease mitigation. Rather, we propose that modifications of this and other treatment options be sought. The results also highlight the need for extended monitoring of CYBD after any treatment, due to the slow but variable rate and pattern of tissue loss in this disease.

\section{Introduction}


44 populations in the Caribbean over the past four decades (Gardner et al. 2003, Weil et al. 2009),

45 and both chronic and acute diseases have, and continue to, hamper coral recovery and restoration

46 efforts throughout the region (Green and Bruckner 2000, Rinkevich 2005, Young et al. 2012).

47 Because coral-disease outbreaks are expected to continue in the future under increasingly

48 stressful environmental conditions (Harvell et al. 2002, Randall and van Woesik 2017), there is

49 an urgent need to develop methods to treat and minimize disease progression.

Caribbean yellow-band disease (CYBD) is a widely distributed and chronic disease that

51 is most commonly observed on the critical reef-building corals in the Orbicella spp. complex

52 (Reeves 1994, Santavy et al. 1999, Cervino et al. 2001, Gil-Agudelo et al. 2004, Weil 2004,

53 Bruckner and Bruckner 2006, Carricart-Ganivet et al. 2011, Soto-Santiago and Weil 2015).

54 Caribbean yellow-band disease is considered to be one of the most severe and lethal coral

55 diseases, as recovery has rarely been observed (but see Weil et al. 2009 and Soto-Santiago and

56 Weil 2015 for seasonal dynamics). This disease was first reported on O. faveolata in the Florida

57 Keys by Reeves (1994), and was subsequently described by Santavy et al. (1999) as yellow-

58 blotch disease in the San Blas Islands of Caribbean Panama. The prevalence of CYBD fluctuates

59 through time, often peaking seasonally with elevated seawater temperatures (Cervino et al. 2001,

60 Croquer and Weil 2009, Weil et al. 2009, Soto-Santiago and Weil 2015, Randall and van Woesik

61 2017). While it was seldom reported prior to the 2005 Caribbean coral-bleaching event, CYBD is

62 now common on many Caribbean reefs, necessitating the urgent development of treatment

63 methods.

64 In the late 1980 s, the first method to treat and manage a coral disease was developed and

65 tested during an outbreak of black-band disease in Looe Key National Marine Sanctuary

66 (Hudson 2000). Researchers used an underwater aspiration system to suction the cyanobacterial 
67 mat off of the coral skeleton, and then used modeling clay, such as Roma plastilina sensu Fisher

68 et al. (2007), to seal the disease-tissue interface (Hudson 2000). After three years, the reinfection

69 rate was low $(\sim 30 \%)$, but black band was still present in the sanctuary, and treatment efforts

70 were slow and laborious. Since then, various additional efforts to control coral-disease outbreaks

71 have been proposed, with mixed success. These efforts include: (i) the use of biological control

72 techniques such as probiotics and phage therapy to manage bacterial pathogens (Efrony et al.

73 2009, Teplitski and Ritchie 2009), (ii) the use of epoxy to mechanically block progression of a

74 tissue-loss disease on Acropora cervicornis (Miller et al. 2014), (iii) the application of chlorine

75 embedded within epoxy to treat and mechanically block progression of black-band disease (Aeby

et al. 2015) and (iv) the excision of healthy coral branch tips from diseased A. cervicornis

77 colonies (Miller et al. 2014). In addition, the mechanical removal of disease vectors, such as the corallivore Coralliophila abbreviata, has been proposed (Gignoux-Wolfsohn et al. 2012) but has not been implemented yet in a large-scale in situ experiment. The success of past mitigation techniques has been variable, and dependent on the host species, the targeted etiological agent, and the disease vectors. For many coral diseases however, etiological agents are unknown, impeding the development of focused treatment methods.

disease caused by a consortium of Vibrio spp. bacterial pathogens that act primarily on the host's symbiotic dinoflagellates (Cervino et al. 2001; 2004a; 2004b; 2008; Croquer et al. 2012). Pinpointing a causative agent has proved challenging, as distinct pathogenic bacteria are not consistently and reproducibly present in diseased tissue (Croquer et al. 2012, Closek et al. 2014, Kimes et al. 2010, Kimes et al. 2013). Furthermore, Koch's postulates have not been definitively satisfied for this disease. However, studies clearly show that the bacterial communities on and in 
90 diseased-coral tissues are distinct from the bacterial communities on and in healthy-coral tissues,

91 and known pathogens are usually present in the diseased tissue (Croquer et al. 2012, Closek et al.

92 2014, Kimes et al. 2010, but see Kimes et al. 2013). Increased prevalence and rates of spread of

93 CYBD lesions also have been associated with several environmental stressors, including

94 anomalously high sea-surface temperatures (Cervino et al. 2004a; 2004b, Croquer and Weil

95 2009, Weil et al. 2009), and high nutrient concentrations (Bruno et al. 2003). In combination,

96 these studies indicate that CYBD may be strongly influenced by the environment. It is also

97 possible that CYBD is caused by endogenous and ubiquitous microbes (sensu Thrusfield 2007)

98 that cause disease when the coral host or the coral symbionts become compromised. Indeed, the

99 proposed causative bacterial pathogens have been found within the natural healthy-coral

100 microbiota (Croquer et al. 2012), but whether this is always true remains unknown and requires

101 further investigation.

102 CYBD significantly and severely reduces reproductive output in $O$. faveolata through

103 several mechanisms, including (i) the direct reduction of live tissue, (ii) the reduction in

104 fecundity of affected polyps and polyps adjacent to the lesion margin, and (iii) fragmentation of

105 large tissue patches resulting in more tissue 'edges' that are non-reproductive, and fewer large

106 and reproductive ramets (Weil et al. 2009). Recent evidence gathered through infrared

107 spectroscopy indicates that energy-rich proteins, carbohydrates, and phospholipidic compounds

108 are reduced in diseased and marginal tissue, presumably leaving less energy for reproduction

109 (Guerra et al. 2014). In addition, evidence suggests that CYBD disproportionately affects the

110 largest $\left(>1 \mathrm{~m}^{2}\right)$ colonies in a population. For example, on a fringing reef off Salar Island,

111 Panama, $70 \%$ of the largest $O$. faveolata colonies had CYBD while only $10 \%$ of all colonies had

112 the disease (Santavy et al. 1999). Large colonies contribute disproportionately more reproductive 
113 material to the population, and by affecting the most fecund individuals, CYBD further limits the

114 recovery potential of the population.

115 Because CYBD is now a common and chronic disease, there is an urgent need to develop

116 methods to treat or slow its progression. Therefore, the objectives of this research were twofold:

117 (1) to evaluate the effectiveness of three mitigation techniques in reducing disease progression;

118 and (2) to refine and quantify the long-term success rate of the most promising technique.

\section{Materials \& Methods}

120 Site selection

121 CYBD is a chronic problem on Caribbean reefs, and has been present within the Buck

122 Island Reef National Monument in St. Croix, US Virgin Islands since at least 2005 (Miller et al.

123 2009). Prior monitoring within the national park identified hotspots of disease on large Orbicella

124 faveolata colonies on the fore reef to the east of Buck Island, at 10-15 m depth (Muller and

125 Randall, unpublished). Therefore, mitigation efforts were tested on colonies in this area with

126 classic signs of the disease, defined as the presence of a gradient of tissue discoloration with

127 apparently normal, thick, and pigmented tissue grading into thinner pale yellow tissue at the

128 dying margin, which is usually smooth with an indistinct edge (sensu Work and Aeby 2006). The

129 algae biofouling community that colonizes the denuded skeleton is visible adjacent to the dying

130 margin, rarely leaving a stark white skeleton. Tissue loss proceeds slowly as the lesion expands,

131 either outwardly from centrally located lesions, or inwardly from peripherally located lesions

132 (see Work and Aeby 2006 for descriptions of terminology). We note that this project was

133 conducted under permit BUIS-2015-SCI-0004.

\section{Objective 1: Test three mitigation techniques}

135 In March 2015, three techniques were tested for their ability to mitigate the progression 
136 of yellow-band lesions on $O$. faveolata colonies (Figure 1). The proposed techniques were

137 selected based on previously published methods for treating other coral diseases, and on the

138 current state of knowledge of disease etiology. Three replicate coral colonies were treated using

139 each mitigation technique, and coral colonies and lesions were measured and photographed, as

140 described in Data Analysis below. Because CYBD lesions spread slowly, coral colonies were

141 revisited after four months in July 2015, and again after seven months in October 2015, and the

142 effectiveness of each technique at reducing the rate of tissue loss was assessed.

143 Technique 1: Shade cloth

144 The first technique involved the application of a shade cloth over the lesion area. This

145 method was selected because the photosymbionts within the coral tissue are known to be affected

146 by CYBD (Cervino et al. 2001; 2004a), and because shading has reduced the rate of tissue loss in

147 other coral diseases (Muller and van Woesik 2009). Reducing light and thus alleviating the

148 potential buildup of harmful reactive oxygen species within coral tissue was hypothesized to

149 increase immune-competence and reduce tissue loss.

150 Prior to deploying the shade cloths, diseased corals were identified in situ, and the lesions

151 were measured and photographed. Custom shade cloths then were made for each lesion. The

152 shade cloths were made of woven brown sun screen fabric $1.57 \mathrm{~mm}$ thick, which is rated to

153 reduce UV light penetration by 75\% (www.homedepot.com/p/6-ft-x-20-ft-Chocolate-Sun-

154 Screen-Fabric-81020R/204631818). The shade cloths were cut to provide full cover of each

155 lesion with an additional $\sim 5 \mathrm{~cm}$ of coverage of apparently healthy tissue beyond the yellow-

156 tissue margin, when the sun was directly overhead. Lesions that were $15-20 \mathrm{~cm}$ long and 3-5 cm

157 wide were targeted for treatment. Shade cloths were sewn around the edges to prevent fraying,

158 and plastic grommets were added to the corners of each shade cloth for attachment. In situ, 
159 masonry nails were placed in each grommet and the shade cloths were installed by hammering

160 the masonry nails into the coral so that the cloth was taut and approximately $7-10 \mathrm{~cm}$ above the

161 tissue surface (Figure 1a). Each treated colony also had at least one band that was left unshaded

162 (absolute control). We note that masonry nail controls were not performed. In October 2015,

163 after seven months of deployment, shade cloths were removed to evaluate the effectiveness of

164 the treatment.

165 Technique 2: Aspiration

166 Underwater aspiration of diseased tissue, followed by sealing the tissue-loss margin with

167 modeling clay, has been used as a successful treatment for black-band disease on Orbicella spp.

168 and other corals in the Caribbean. Hudson (2000) first developed this treatment and kindly

169 provided his plans, which were used to custom build an underwater aspirator (Figure 2). Briefly,

170 the aspirator works by injecting air into a hose that runs to the surface, creating a powerful

171 siphon. The resulting suction is then used to remove diseased tissue from the coral skeleton,

172 which is collected in a container at the surface.

173 Our aspiration system consisted of 5 components (Figure 2): (1) an air delivery system;

174 (2) an aspiration chamber; (3) a suction hose with a stainless steel tip; (4) a discharge hose; and

175 (5) a collection container. The air was delivered via a standard SCUBA air cylinder with a

176 single-hose regulator, and a pressure gauge. Approximately 2 meters of air hose was connected

177 to a low-pressure port, and on the end of the air hose was the suction tube made of $1 \mathrm{~cm}$ diameter

178 stainless steel tubing $\sim 15 \mathrm{~cm}$ long and angled at the tip to be used flush against the coral tissue.

179 The suction hose was connected to the aspiration chamber and air flow into the chamber was

180 provided by the SCUBA tank and controlled by a mechanic's air gun. Injected air created suction

181 through the hose, similar to an airlift pump, and collected the diseased tissue through a discharge 
182 hose. The discharge hose was a $21 \mathrm{~m}$ (70 ft.) standard pool hose, which was fed into a $208 \mathrm{~L}$ (55

183 gal) trash bin on a boat above the divers. The effluent then was run through an ultraviolet light

184 sterilizer (CoralLife Turbo Twist 6x) and fed back into the surface water. The aspirator was used

185 to remove all visible diseased tissue (band $\sim 15-20 \mathrm{~m}$ long and 3-5 $\mathrm{cm}$ wide) on three replicate

186 coral colonies (Figure 1b). Because the goal was to completely eradicate the disease from the

187 colonies, no corals that were aspirated had untreated (absolute control) bands. Corallites were

188 scraped with the stainless steel tube to remove as much tissue within the skeleton as possible, but

189 small bits of tissue $<1 \mathrm{~mm}^{2}$ remained in some skeletal crevices that were unreachable by the

190 aspiration tube. No sealant was used along the aspirated margin in this study, and no procedural

191 control for the aspirator was performed. The colonies were visually assessed at four months and

192 seven months after aspiration.

193 Technique 3: Chiseling a firebreak

194 The third technique involved the creation of a 'firebreak' or trench between the lesion

195 and the adjacent apparently healthy tissue, using a hammer and chisel (Figure 1c). Several

196 studies suggest that CYBD is caused by a bacterial pathogen or consortium of pathogens, which

197 is largely isolated within the bacterial community of the diseased tissue (Croquer et al. 2012,

198 Closek et al. 2014, Kimes et al. 2010). If the pathogenic microorganisms causing CYBD are

199 localized to the tissue within and around the lesion, we hypothesized that isolating the diseased

200 tissue from the apparently healthy tissue could treat CYBD.

201 Three diseased-coral colonies were identified and one lesion on each colony was treated

202 via chiseling. When present, any remaining lesions were left untreated and served as controls. A

203 'firebreak' was established to encircle the entire lesion, with a $\sim 1 \mathrm{~cm}$ margin of healthy-

204 appearing tissue remaining between the firebreak and the yellow-tissue margin as a 'buffer' to 
205 ensure that we did not chisel directly into visibly diseased tissue (Figure 1c). The trench created

206 by the chisel was approximately $1 \mathrm{~cm}$ deep and $1 \mathrm{~cm}$ wide, with the complete separation of tissue

207 on either side of the 'firebreak' (Figure 1c).

208 Data Analysis

To limit the introduction of physical objects into the National Park, we collected data

210 using photographic techniques, which utilized physical features present within each colony as

211 reference points. Photographs of all control and treated coral colonies were taken using a Canon

212 Powershot G15 in a Canon underwater housing WP-DC48 waterproof case. Photographs were

213 taken in Program Mode, using the Underwater Setting and auto-focus. Images were batch post-

214 processed in Adobe Photoshop to remove blue hues and color balance the images. Each image

215 was taken roughly $1 \mathrm{~m}$ away from the coral colony at approximately the same angle. Each image

216 included a $50 \mathrm{~cm}$ scale bar, marked in $10 \mathrm{~cm}$ increments, placed parallel to the lesion. Multiple

217 images of each colony were taken at each time point to ensure that there were comparable

218 images across sampling periods.

219 To estimate the rate of tissue loss $\left(\mathrm{cm} \mathrm{mo}^{-1}\right)$ of both control and treated lesions, a 'guide

220 line' was placed on each image, parallel to each lesion, using skeletal features as a reference

221 (Figure 3). Three to five reference points were placed equidistant on the guide line, and the

222 perpendicular distance from each point to the coral tissue was measured. The distance of each

223 reference point in March 2015 was subtracted from the distance of the same reference point in

224 October 2015, and those differences were averaged to obtain a single estimate of the rate of

225 linear tissue over this period for each colony (Figure 3). We note that although slight variations

226 in distance and angle may have been introduced, the use of three to five reference points aided in

227 the reduction of measurement variability. A one-tailed, paired t-test was used to test whether the 
228 shaded bands spread more slowly than the control bands on each of the shaded colonies $(n=3)$.

229 For the aspirated and chiseled corals, the average rates of tissue-loss (i.e. the rates of spread) of

230 the treated bands were compared with the control bands (on the shaded corals) using a one-tailed

231 t-test. All calculations were performed in the R statistical program (R Core Team 2017).

232 Objective 2: Refine and quantify long-term success of the chiseling technique

233 Following the promising preliminary results from objective 1, a more robust and long-

234 term analysis of the chiseling method was tested. In July 2015, 19 additional corals with yellow-

235 band disease were identified and marked with a cattle tag. At least one band was chiseled on

236 each tagged colony and, when present, additional bands on those colonies were left untreated as

237 controls. The trenches were further standardized, and chiseled $1 \mathrm{~cm}$ wide and $1 \mathrm{~cm}$ deep to create

238 a substantial barrier between the lesion and the remaining apparently healthy coral tissue. In

239 addition, two corals that had been chiseled in March 2015 were re-chiseled in spots where the

240 apparently healthy tissue had filled in the chiseled groove and reconnected with the lesion. In

241 October 2015, another 11 colonies were identified, tagged, and treated. In total, eleven colonies

242 were followed for sixteen months, 19 additional colonies were followed for 19 months, and the

243 original three colonies were tracked for 23 months, for a total of 33 coral colonies treated. Of

244 those colonies, 19 had control bands.

245 All chiseled corals were revisited in March 2016 and again in February 2017. During

246 every evaluation, the condition of each chiseled lesion was classified into one of three categories:

247 (1) 'healthy', defined as a healed tissue margin with no grossly visible signs of disease beyond

248 the chisel line and no reconnection with diseased tissue, (2) 'moderate', defined as a healed

249 tissue margin and no tissue loss past the chisel line, but the apparently healthy tissue reconnected

250 with the lesion, and (3) 'poor', defined as tissue loss past the chisel line and active yellow band 
251 signs (Figure 4). We note that the categories were applied to the treated lesion only, and not the

252 entire colony, as many colonies had untreated lesions (controls) present in other areas. The rates

253 of tissue loss of the treated and control bands were measured from paired images taken at the

254 time of treatment and again in February 2017, as described above. A one-tailed, paired t-test was

255 used to determine whether rates of tissue loss of chiseled lesions were significantly reduced

256 compared with the control lesion on the same colonies, and a one-tailed t-test was used to

257 compare rates of tissue loss of all control bands with all treated bands. All tissue-loss rate data

258 were $\log$ transformed to meet the assumptions of the parametric tests. All calculations were

259 performed in the R statistical program (R Core Team 2017). Posthoc power analyses were

260 undertaken to determine the power to detect an effect size of 0.8 (large effect) with an alpha error

261 probability of 0.1 (Type I error rate) for all treatment techniques for Objectives 1 and 2, when no

262 statistical differences were detected ( $\mathrm{G}^{*}$ Power 3.0.10).

\section{Results}

\section{Objective 1: Testing three mitigation techniques}

265 Technique 1: Shade cloth

After four months, all shade cloths remained secure and standing; the exception was one corner nail that had come loose on one cloth, which still provided a majority of the shading to the coral. All shade cloths, however, had become bio-fouled, effectively reducing light penetration to near $0 \%$. Therefore, the only appreciable light reaching the coral tissue came indirectly, from ambient light around the cloth. In July of 2015, the loose nail was re-attached and all shade

271 cloths were scrubbed with a wire brush to remove biofouling organisms. In October of 2015,

272 after seven months, the shade cloths were removed and the lesions were assessed and 273 photographed. 
All three shaded lesions continued to spread and cause tissue mortality (Figures 5 and

275

276

277

278

279

280

281

282

283

284

285

286

287

288

289

290

291

292

293

294

295

296

6a). The lesions spread approximately $0.4 \mathrm{~cm}$ per month and the rate of spread was not significantly reduced under the shade cloth compared with the control bands (paired one-tailed ttest: $\mathrm{t}=-0.79, \mathrm{df}=4, \mathrm{p}=0.76)$. The width of discolored tissue also increased and the lesion bleached under the shade cloth (Figure 5). We note that no negative effects resulting from the masonry nails were observed, and five months after the nail removal, the holes left by the nails had begun to heal (Supplementary Figure 1).

\section{Technique 2: Aspiration}

All three coral colonies that were aspirated resheeted tissue over the abraded and aspirated area within four months (Figure 5). The tissue that resheeted over the aspirated area regrew polyps and coenosarcal tissue and was yellow, either having resheeted as diseased, or having resheeted as apparently healthy but subsequently became diseased. Resheeted tissue generally appeared visually normal in structure, although a few areas with skeletal structures that were heavily damaged during aspiration (i.e. broken corallite walls and septo-costae) had less well developed polyps. Despite some tissue regrowth, the yellow-band lesions continued to spread and cause tissue loss on the colonies. After seven months, tissue loss was comparable with control bands on the shaded colonies, advancing an average of $0.4 \mathrm{~cm}$ per month (one-tailed t-test: $\mathrm{t}=-0.17, \mathrm{df}=2.62, \mathrm{p}=0.56)$.

\section{Technique 3: Chiseling a firebreak}

In July 2015, the margins of all three colonies that were chiseled had healed, and they looked apparently healthy in most areas. On two colonies, tissue regrowth over the 'firebreak' reconnected the remainder of the colony with the lesion in a few small sections. However, in cases where the lesion and the main colony had not reconnected, the main colony appeared to be 
297 healthy. Yellow band was active on the lesion that was separated from the main colony, and that

298 isolated tissue bleached and died at a higher rate (Figure 5, see July 2015). The rate of tissue loss

299 was not significantly reduced by the chiseling method (one-tailed $t$-test: $t=-0.17, \mathrm{df}=2.62$,

$300 \mathrm{p}=0.56$; Figure $6 \mathrm{a}$ ), but no tissue was lost past the firebreak.

301 A posthoc power analysis indicated that the power to detect an effect size of 0.8 with an

302 alpha error probability of 0.1 was $0.70($ critical $t=2.015)$ for the shaded corals and 0.4 (critical $t$

$303=1.440)$ for the aspirated and chiseled corals $(\mathrm{G} *$ Power 3.0.10).

304 Objective 2: Refining and quantifying long-term success of the chiseling technique

305 In March 2016, 16 of the colonies treated with the chiseling technique (48\%) showed

306 signs of local recovery, defined as a healed-tissue margin and no grossly visible signs of the

307 disease past the firebreak or around the treated area (Figures 4 and 7; Table 1). An additional

$30833 \%$ of colonies showed moderate recovery, defined as a healthy and healed chisel margin but

309 some tissue reconnection with the lesion. By February 2017, however, only the tissue around

310 seven of the treated lesions remained apparently healthy, reducing the recovery rate to $21 \%$

311 (Table 1). When the treatment date was taken into account, the time series clearly indicates a

312 steady and significant decline in the condition of the treated colonies, from more than $70 \%$

313 appearing healthy 5 months post-treatment, to less than $10 \%$ appearing healthy by 19 months

314 post-treatment (Figure 8).

315 Overall, the rate of tissue loss on chiseled lesions was significantly reduced compared

316 with control lesions, from an average of $0.31 \mathrm{~cm} \mathrm{mo}^{-1}$ on control lesions to $0.22 \mathrm{~cm} \mathrm{mo}^{-1}$ on

317 treated lesions (paired, one-tailed t-test for all colonies with paired control and treatment bands:

$318 \mathrm{t}=-2.19, \mathrm{df}=17, \mathrm{p}=0.005$; Figure $6 \mathrm{~b}$ ). This reduction was likely a consequence of similar rates of

319 tissue loss on control and treated colonies until the firebreak was reached, where the disease was 
320 slowed or halted entirely. In addition, one colony experienced complete mortality and another

321 colony experienced a skeletal break, therefore rates of tissue loss could only be measured on 31

322 colonies.

323

324 Discussion

Caribbean yellow-band disease (CYBD) is one of the most common coral diseases found

326

327

328

329

330

331

332

333

334

335

336

338

339

340

341

342

within the Buck Island Reef National Monument (BIRNM), in St. Croix, U.S. Virgin Islands, and is significantly impacting the Orbicella faveolata populations in the park. There is an urgent need to slow or stop the spread of CYBD on these colonies, in order to preserve the O. faveolata population and increase the population's recovery potential. Results from the experiments presented here indicate that shading and aspirating yellow-band lesions are not effective treatments. While the power to detect an effect of the shading and aspirating techniques was fairly low, the return of grossly visible signs of disease on all treated bands indicated that there is poor viability of these techniques. Chiseling a 'firebreak' to isolate the diseased tissue was successful at reducing rates of tissue loss by one third, but due to the poor long-term prognosis, chiseling is not recommended for the treatment of CYBD without additional method development.

Shading corals in an effort to slow the tissue loss resulting from various diseases historically has had mixed results. Reducing photosynthetically available radiation (PAR) by $40 \%$ significantly slowed the rate of tissue loss resulting from white-plague disease on Colpophyllia natans (Muller and van Woesik 2009). However, shading corals with black-band disease increased the rate of tissue loss (Muller and van Woesik 2011). CYBD is thought to be an infection of the endosymbiont (Symbiodinium spp.) cells (Cervino et al. 2001; 2004a; 2004b; 
343 2008, Croquer et al. 2012, but see Correa et al. 2009), which can eventually lead to the death of

344 the host. If CYBD is caused by opportunistic infections of endogenous pathogenic

345 microorganisms, it is likely that the best treatment techniques will be those that reduce stress on

346 the host's innate immune system, and directly treat the bacterial infection. Shading corals may

347 partly reduce stress from high irradiance, but without concurrent treatment of the infection, it

348 may not reduce the virulence of the pathogen(s). Indeed, shading alone did not reduce tissue loss

349 in the present experiment, although we note that the entire colony was not shaded, and that

350 eventually the shade cloth became biofouled, significantly reducing light penetration. The

351 manipulative light levels may have been too low, causing light limitation. Alternatively,

352 irradiance levels may have a negligible influence on the dynamics of CYBD.

353 The lack of success with the aspiration method was not surprising. Aspiration of black-

354 band cyanobacterial mats is probably successful because the pathogenic consortium is found on

355 the outer surface of the coral tissue, rather than embedded within the tissue, making the removal

356 of the mat fairly easy. We hypothesize that aspirating CYBD tissue was not successful because

357 the apparently healthy tissue regrew and reconnected with small lesion-tissue fragments that

358 remained in the corallites that were not removable with the aspirator. That recovered tissue then

359 began to show signs of CYBD, suggesting that either: (i) the diseased-tissue fragments remained

360 actively infected and transmitted the pathogenic microorganisms to the re-growing tissue, or (ii)

361 that the pathogens were already present in the healthy-appearing tissue and took time to manifest

362 macroscopically, or (iii) the pathogens may reside within the skeletal matrix and re-infect the

363 host. Regardless of the mechanism, the aspiration technique was not successful to treat CYBD.

364 Furthermore, aspirating diseased tissue was extremely labor intensive and required the use of a

365 surface supply technique while live boating. Therefore, we do not recommend the use of 
366 aspiration in CYBD mitigation efforts beyond a narrow scope.

367 The initially promising results from the chiseling technique became discouraging as the

368 condition of the treated colonies declined over time. However, in the few cases when the isolated

369 diseased tissue died before reconnecting with the host coral, the coral healed and remained

370 apparently healthy over many months. In other words, the best-case coral response occurred

371 when the isolated, diseased tissue died rapidly and completely, preventing the apparently healthy

372 tissue from re-connecting with the lesion. We also observed that firebreaks too close to the active

373 area of tissue-loss allowed the disease to spread past the chisel mark easily. Additional

374 experiments to optimize the chiseling technique are on-going and will identify the best time of

375 year to chisel, the ideal depth and width of the 'firebreak', the ideal placement of the 'firebreak'

376 relative to the lesion margin, and the effectiveness of an epoxy application with peroxide or

377 broad-spectrum antibiotics along the firebreak. Furthermore, the development of treatment

378 methods that quickly and completely kill the isolated diseased tissue are being developed. We

379 hypothesize that chiseling in late spring may be the best time of year as warm temperatures

380 accelerate the spread of the disease (Cervino et al. 2004b) and may cause rapid loss of the

381 diseased tissue before regrowth and reconnection can occur. However, coral growth also

382 accelerates as waters warm (Carricart-Ganivet 2004) potentially increasing the probability of

383 reconnection between apparently healthy and diseased tissue. Further testing of these hypotheses,

384 techniques, and applications are needed to determine whether the firebreak approach has any

385 long-term viability.

386 In general, yellow-band disease spreads slowly, but the rate of tissue loss responds to

387 changes in ambient conditions. Cervino et al. (2004) documented a significant increase in the

388 rate of tissue loss of CYBD on Orbicella spp. colonies that were inoculated with putative CYBD 
389 pathogens and maintained at $33{ }^{\circ} \mathrm{C}$ compared with controls at $20{ }^{\circ} \mathrm{C}$, but those rates were orders

390 of magnitude higher than those measured in the present study (measured in $\mathrm{cm}$ per hr), which are

391 likely a result of the high concentration of pathogens in the inoculum. Also, Bruno et al. (2003)

392 found that increased nutrient concentrations nearly doubled the rate of CYBD tissue loss on

393 Orbicella spp., from around $0.3 \mathrm{~cm}$ per month to $0.6 \mathrm{~cm}$ per month. In the first set of trials, our

394 rates of tissue loss averaged approximately $0.4 \mathrm{~cm}$ per month from July to October 2015. During

395 the longer-term test of the chiseling technique, however, the average rate of tissue loss was

396 closer to $0.3 \mathrm{~cm}$ per month. These results support previous findings that CYBD tissue loss is

397 faster during the warm summer months than the cool winter months.

398 While the data are limited, it is noteworthy that the virulence of the CYBD pathogens at

399 Buck Island appears to be significantly lower than it was in Puerto Rico 10-15 years ago. Weil et

400 al. (2009) measured rates of tissue loss of $0.6 \mathrm{~cm}$ per month in 2001-2003, but a 4-fold higher

401 rate in 2007 (2.2 cm per mo), after the 2005 mass bleaching and disease event. These data could

402 indicate that the virulence of the CYBD pathogens has decreased in the region since 2007.

403 Indeed, fewer CYBD cases have been noted in the Florida Keys and in Bonaire in recent years,

404 compared with the early 2000s (E. Peters, pers. comm. 2018). Alternatively, it is possible that the

405 resistance of host populations to the CYBD pathogens has increased, or that methodological

406 differences between studies in measuring rates of tissue loss led to the apparent decrease. Thus,

407 additional research is needed to formally test this hypothesis.

\section{Conclusions}

409 Although preventing coral diseases is the best approach, ubiquitous and endogenous

410 pathogens that become more virulent in a warming ocean will likely continue to cause tissue loss

411 in corals. Armed with mitigation techniques, managers may be able to work within coral 
412 restoration programs to prevent the further loss of corals after infection occurs, ultimately

413 maintaining coral populations. While we do not support the use of the chiseling approach in its

414 current state, additional methods that complement the chiseling technique and increase its

415 effectiveness may become especially important as CYBD continues to affect the largest colonies

416 that often contribute the most towards sexual reproduction within a population. Different

417 causative agents necessitate different treatment techniques. Consequently, continuing research to 418 pinpoint disease etiology will enable the tailoring of future treatments to the disease.

\section{Acknowledgements}

421

422

423

424

425

426

427

428

429

430

431

432

433

434

435

436

437

438

439

Many thanks to Nathaniel Hanna Holloway and Constance Sartor for invaluable field assistance.

We also thank Monty Clark for assistance with the development of the underwater aspirator, and Justin Speaks for editorial comments.

\section{References}

Aeby, G.S., Work, T.M., Runyon, C.M., Shore-Maggio, A., Ushijima, B., Videau, P., Beurmann, S. and Callahan, S.M. (2015). First record of black band disease in the Hawaiian archipelago: response, outbreak status, virulence, and a method of treatment. PloS one, 10(3), e0120853.

Bruckner, A. W., \& Bruckner, R. J. (2006). Consequences of yellow band disease (YBD) on Montastraea annularis (species complex) populations on remote reefs off Mona Island, Puerto Rico. Diseases of Aquatic Organisms, 69(1), 67-73.

Bruno, J. F., Petes, L. E., Drew Harvell, C., \& Hettinger, A. (2003). Nutrient enrichment can increase the severity of coral diseases: Effect of nutrients on coral disease severity. Ecology Letters, 6(12), 1056-1061.

Carricart-Ganivet, J. (2004) Sea surface temperature and the growth of the West Atlantic reefbuilding coral Montastraea annularis. Journal of Experimental Marine Biology and Ecology, 302, 249-260. 
440

441

442

443

444

445

446

447

448

449

450

451

452

453

454

455

456

457

458

459

460

461

462

463

464

465

466

467

468

469

470

471

472

473

474
Carricart-Ganivet, J., Beltrán-Torres, A., \& Horta-Puga, G. (2011). Distribution and prevalence of coral diseases in the Veracruz Reef System, Southern Gulf of Mexico. Diseases of Aquatic Organisms, 95(3), 181-187.

Cervino, J. M., Goreau, T. J., Nagelkerken, I., Smith, G. W., \& Hayes, R. (2001). Yellow band and dark spot syndromes in Caribbean corals: distribution, rate of spread, cytology, and effects on abundance and division rate of zooxanthellae. In: The Ecology and Etiology of Newly Emerging Marine Diseases (pp. 53-63) Springer Netherlands.

Cervino, J. M., Hayes, R., Goreau, T. J., \& Smith, G. W. (2004a). Zooxanthellae regulation in yellow blotch/band and other coral diseases contrasted with temperature related bleaching: In situ destruction vs expulsion. Symbiosis-Rehovot, 37(1/3), 63-86.

Cervino, J. M., Hayes, R. L., Polson, S. W., Polson, S. C., Goreau, T. J., Martinez, R. J., \& Smith, G. W. (2004b). Relationship of vibrio species infection and elevated temperatures to yellow blotch/band disease in Caribbean corals. Applied and Environmental Microbiology, 70(11), 6855-6864.

Cervino, J. M., Thompson, F. L., Gomez-Gil, B., Lorence, E. A., Goreau, T. J., Hayes, R. L., Winiarski-Cervino, K. B., Smith, G. W., Hughen, K., \& Bartels, E. (2008). The Vibrio core group induces yellow band disease in Caribbean and Indo-Pacific reef-building corals. Journal of Applied Microbiology, 105(5), 1658-1671.

Closek, C. J., Sunagawa, S., DeSalvo, M. K., Piceno, Y. M., DeSantis, T. Z., Brodie, E. L., Webster M. X., Voolstra, C. R., Andersen, G. L., \& Medina, M. (2014). Coral transcriptome and bacterial community profiles reveal distinct yellow band disease states in Orbicella faveolata. The ISME Journal, 8(12), 2411-2422.

Correa, A. M. S., Brandt, M. E., Smith, T. B., Thornhill, D. J., \& Baker A. C. (2008). Symbiodinium associations with diseased and healthy corals. Coral Reefs. DOI: 10.1007/s00338-008-0464-6

Cróquer, A., \& Weil, E. (2009). Changes in Caribbean coral disease prevalence after the 2005 bleaching event. Diseases of Aquatic Organisms, 87, 33-43.

Cróquer, A., Bastidas, C., Elliott, A., \& Sweet, M. (2012). Bacterial assemblages shifts from healthy to yellow band disease states in the dominant reef coral Montastraea faveolata. Environmental Microbiology Reports. doi:10.1111/j.1758-2229.2012.00397.x

Efrony, R., Atad, I., \& Rosenberg, E. (2009). Phage therapy of coral white plague disease: properties of phage BA3. Current Microbiology, 58(2), 139-145.

Fisher, E. M., Fauth, J. E., Hallock, P., \& Woodley, C. M. (2007). Lesion regeneration rates in reef-building corals Montastraea spp. as indicators of colony condition. Marine Ecology Progress Series, 339, 61-71. 
475 Gardner, T. A., Côté, I. M., Gill, J. A., Grant, A., \& Watkinson, A. R. (2003). Long-term region-

476

477

478

479

480

481

482

483

484

485

486

487

488

489

490

491

492

493

494

495

496

497

498

499

500

501

502

503

504

505

506

507 508 wide declines in Caribbean corals. Science, 301(5635), 958-960.

Gignoux-Wolfsohn, S. A., Marks, C. J., \& Vollmer, S. V. (2012). White Band Disease transmission in the threatened coral, Acropora cervicornis. Scientific Reports, 2.

Gil-Agudelo, D. L., Smith, G. W., Garzón-Ferreira, J., Weil, E., \& Petersen, D. (2004). Dark spots disease and yellow band disease, two poorly known coral diseases with high incidence in Caribbean reefs. In: Coral health and disease (pp. 337-349) Springer, Berlin, Heidelberg.

Guerra, M., López, M. A., Estéves, I., Zubillaga, A. L., \& Cróquer, A. (2014). Fouriertransformed infrared spectroscopy: a tool to identify gross chemical changes from healthy to yellow band disease tissues. Diseases of aquatic organisms, 107(3), 249-258.

Green, E. P., \& Bruckner, A. W. (2000). The significance of coral disease epizootiology for coral reef conservation. Biological Conservation, 96(3), 347-361.

Harvell, C. D., Mitchell, C. E., Ward, J. R., Altizer, S., Dobson, A. P., Ostfeld, R. S., \& Samuel, M. D. (2002). Climate warming and disease risks for terrestrial and marine biota. Science, 296(5576), 2158-2162.

Hudson, J.H., 2000. First aid for massive corals infected with black band disease, Phormidium corallyticum: An underwater aspirator and post-treatment sealant to curtail reinfection. In Diving for Science in the 21st Century (Hallock, P. and French, L., eds), pp. 10-11, American Academy of Underwater Sciences.

Kimes, N. E., Van Nostrand, J. D., Weil, E., Zhou, J., \& Morris, P. J. (2010). Microbial functional structure of Montastraea faveolata, an important Caribbean reef-building coral, differs between healthy and yellow-band diseased colonies. Environmental Microbiology, $12(2), 541-556$.

Miller, M. W., Lohr, K. E., Cameron, C. M., Williams, D. E., \& Peters, E. C. (2014). Disease dynamics and potential mitigation among restored and wild staghorn coral, Acropora cervicornis. PeerJ, 2, e541.

Muller, E. M., \& van Woesik, R. (2009). Shading reduces coral-disease progression. Coral Reefs, 28(3), 757-760.

Muller, E. M., \& van Woesik, R. (2011). Black-band disease dynamics: Prevalence, incidence, and acclimatization to light. Journal of Experimental Marine Biology and Ecology, 397(1), $52-57$.

R Core Team (2017). R: A language and environment for statistical computing. R Foundation for Statistical Computing, Vienna, Austria. 
509 Randall, C.J. \& van Woesik, R., (2017). Some coral diseases track climate oscillations in the Caribbean. Scientific Reports, 7(1), p.5719.

511 Reeves, L. (1994). Newly discovered: Yellow band disease strikes Keys Reefs. Underwater USA

Rinkevich, B. (2005). Conservation of coral reefs through active restoration measures: recent approaches and last decade progress. Environmental Science \& Technology, 39(12), 43334342.

Santavy, D. L., Peters, E. C., Quirolo, C., Porter, J. W., \& Bianchi, C. N. (1999). Yellow-blotch

Soto-Santiago, F.J. and Weil, E., (2014). Spatial and temporal variability of Caribbean yellow band disease prevalence in Orbicella spp. off La Parguera, Puerto Rico. Caribbean Journal of Science, 48(2-3), pp.81-102.

Teplitski, M., \& Ritchie, K. (2009). How feasible is the biological control of coral diseases?. Trends in Ecology \& Evolution, 24(7), 378-385.

Thrusfield, M. (2007). Veterinary Epidemiology $3^{\text {rd }}$ Edition. Butterworth-Heinemann Ltd. Weil, E. (2004). Coral reef diseases in the wider Caribbean. In: Coral health and disease (pp. 3568) Springer, Berlin, Heidelberg.

Work, T. M., \& Aeby, G.S. (2006) Systematically describing gross lesions in corals. Diseases of

Weil, E., Cróquer, A., \& Urreiztieta, I. (2009). Yellow band disease compromises the reproductive output of the Caribbean reef-building coral Montastraea faveolata (Anthozoa, Scleractinia). Diseases of Aquatic Organisms, 87(1-2), 45-55.

Young, C. N., Schopmeyer, S. A., \& Lirman, D. (2012). A review of reef restoration and coral propagation using the threatened genus Acropora in the Caribbean and Western Atlantic. Bulletin of Marine Science, 88(4), 1075-1098. 


\section{Figure 1}

Three disease mitigation techniques.

Three disease-mitigation techniques that were tested on Caribbean yellow-band disease on Orbicella faveolata. The first method was the application of a shade cloth over the lesion (A). The second technique involved the aspiration of tissue from the lesion (B). The third technique was the chiseling of a 'firebreak' around the lesion to separate it from the healthy-appearing tissue on the coral colony (C). Arrow in (B) indicates area of aspirated tissue. Arrow in (C) indicates chisel line. Photo credit: C. J. Randall.
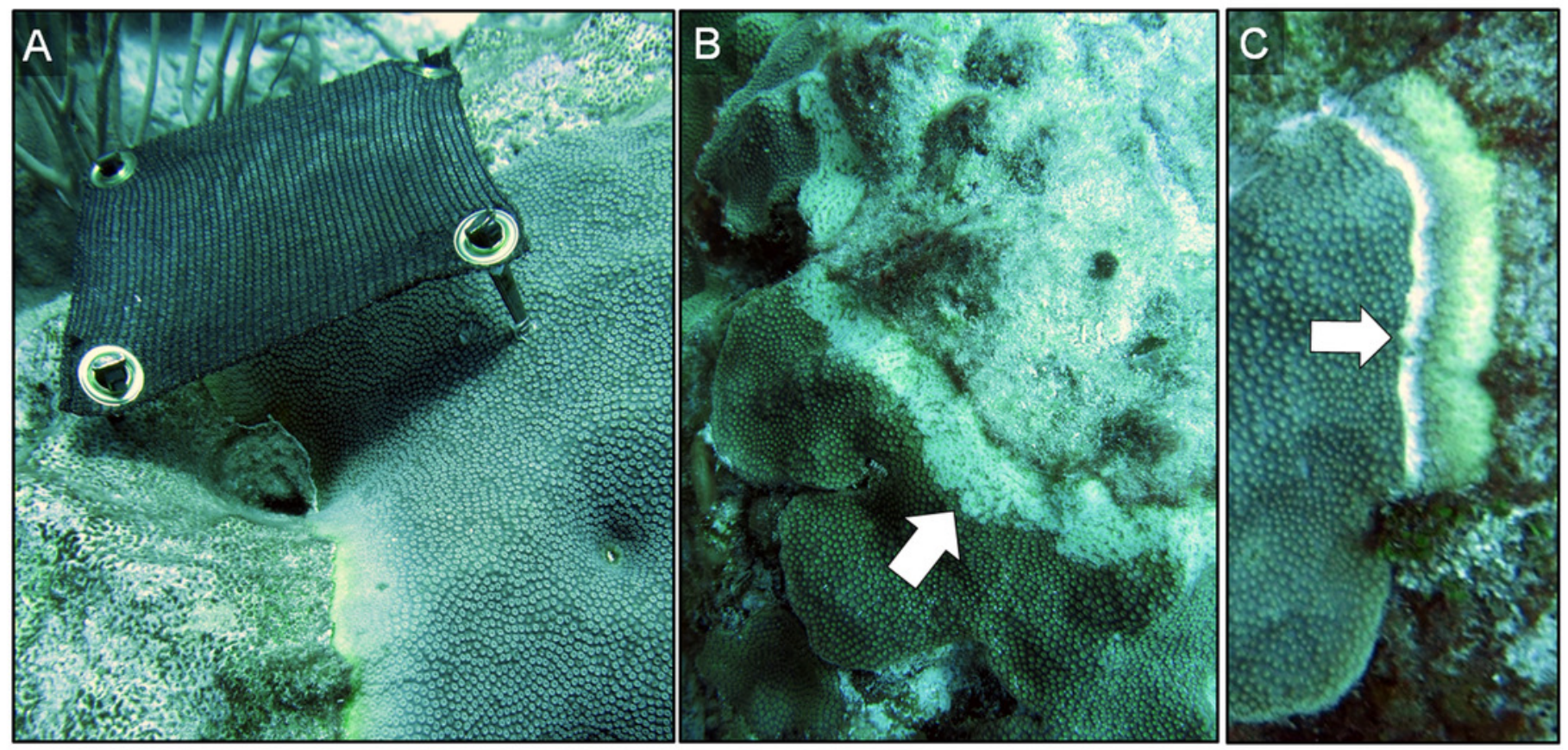
Figure 2

Underwater aspiration apparatus.

The underwater aspiration apparatus developed after Hudson (2000). Photo credit: C. J. Randall. 


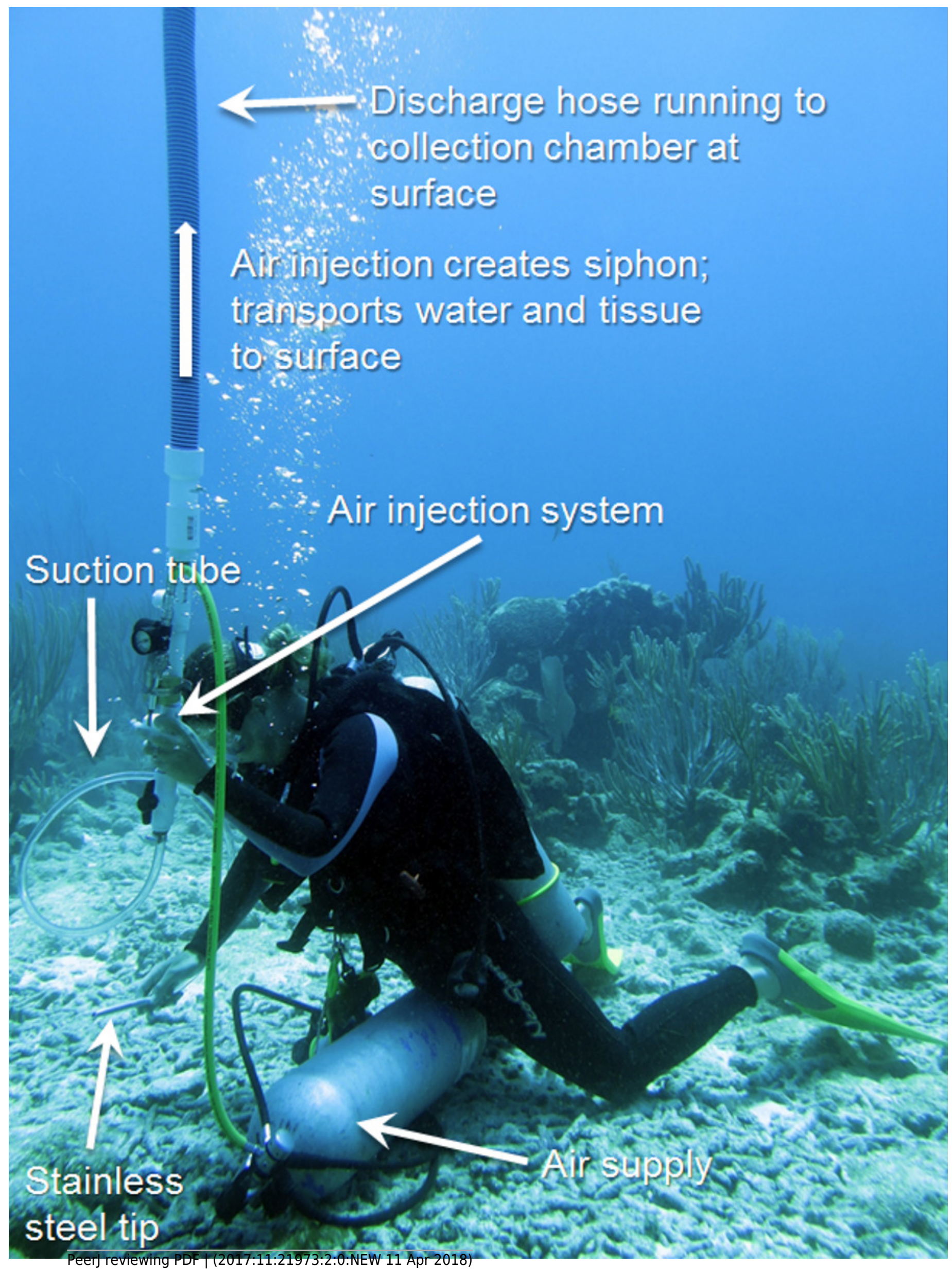




\section{Figure 3}

Estimating disease progression.

Method to estimate the rate of tissue loss from Caribbean yellow-band disease on Orbicella faveolata. The 'guide line' (yellow) with reference points was placed on each colony, and the perpendicular distance from each point to the coral-tissue margin was measured and the difference in distance between time 1 (A) and time 2 (B) was calculated. The distance from each reference point was averaged to estimate a colony-wide rate of tissue loss. Photo credit: C. J. Randall.
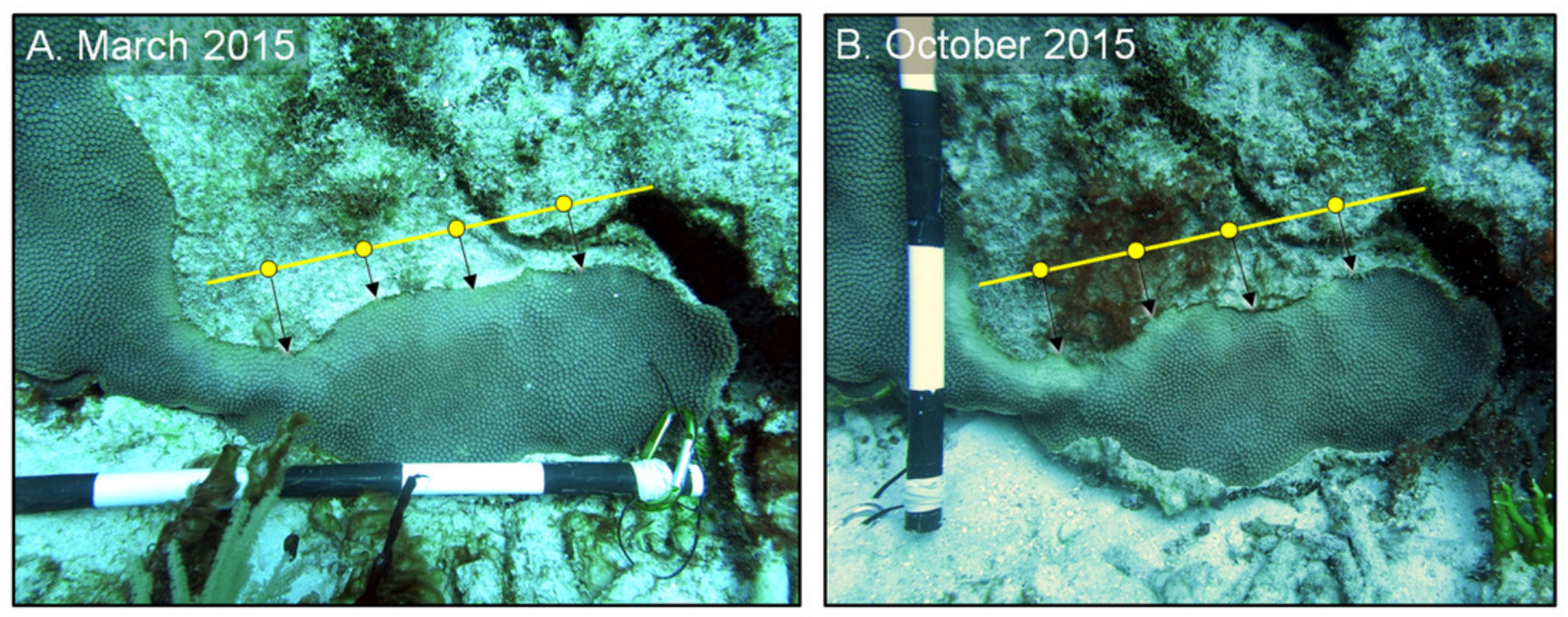


\section{Figure 4}

Example images of healthy, moderate, and poor condition corals.

Images of Orbicella faveolata colonies treated with the chiseling technique that were classified into one of three categories: (A) 'healthy'; (B) 'moderate'; and (C) 'poor'. See text for category definitions. Arrows indicate the location of the chisel line on each colony. Photo credit: C. J. Randall.
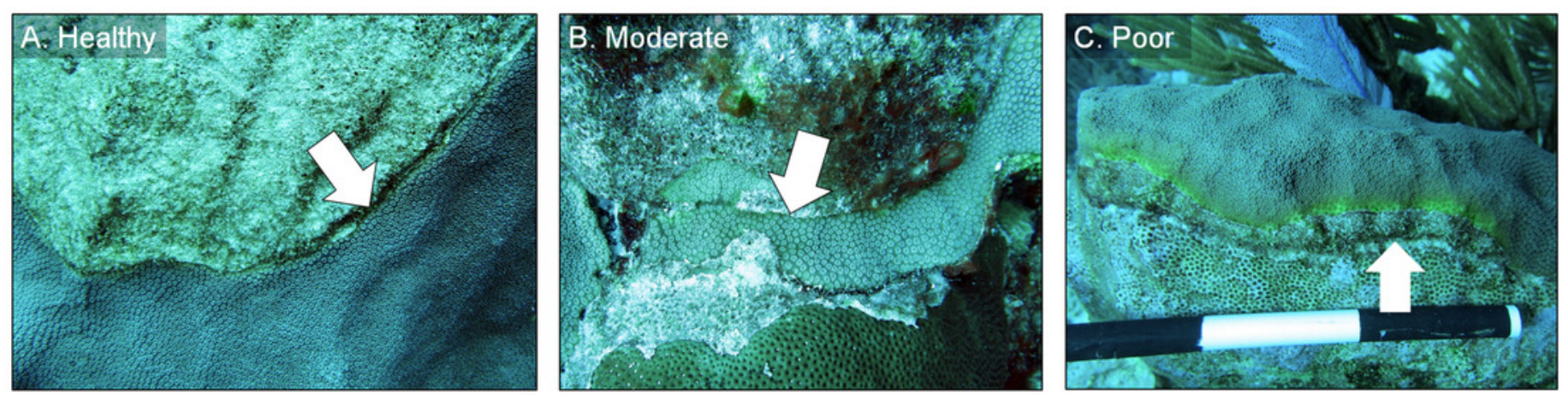


\section{Figure 5}

Example of the results of three mitigation techniques.

Time series photographs of Orbicella faveolata colonies that were treated with one of three techniques to mitigate Caribbean yellow-band disease (shading [A-D], aspiration [E-G] and chiseling [I-K]). Corals were treated in March 2015 and revisited in July and October 2015. Arrows in $\mathrm{F}-\mathrm{H}$ indicate the region of aspirated tissue on the colony and arrows in I-K indicate the chisel line on the colony. Photo credit: C. J. Randall.
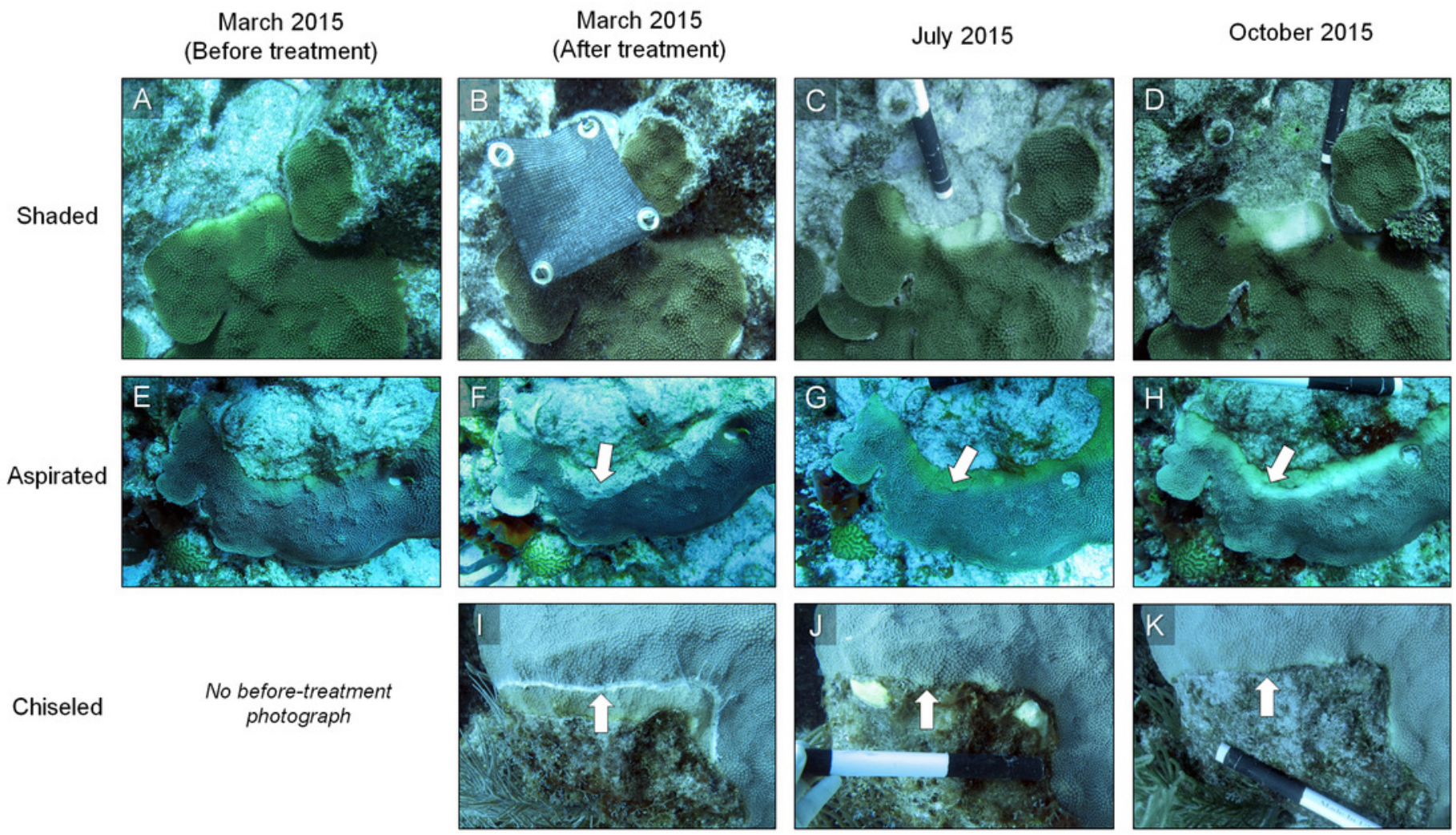


\section{Figure 6}

Rates of tissue loss from Caribbean yellow-band disease.

Average rate of tissue loss ( $\mathrm{cm} \mathrm{mo}^{-1}$ ) of yellow-band disease on Orbicella faveolata. A. Objective 1 trials comparing aspirated, shaded, and chiseled bands with the untreated bands ('Control'). Tissue loss was measured from the initial tissue margin to the final tissue margin.

B. Objective 2 trials comparing chiseled bands with the untreated bands ('Control'). ' $n$ ' indicates sample size for each treatment. ' $*$ ' indicates a statistically significant differences in progression rate compared with the control $(p<0.05)$.

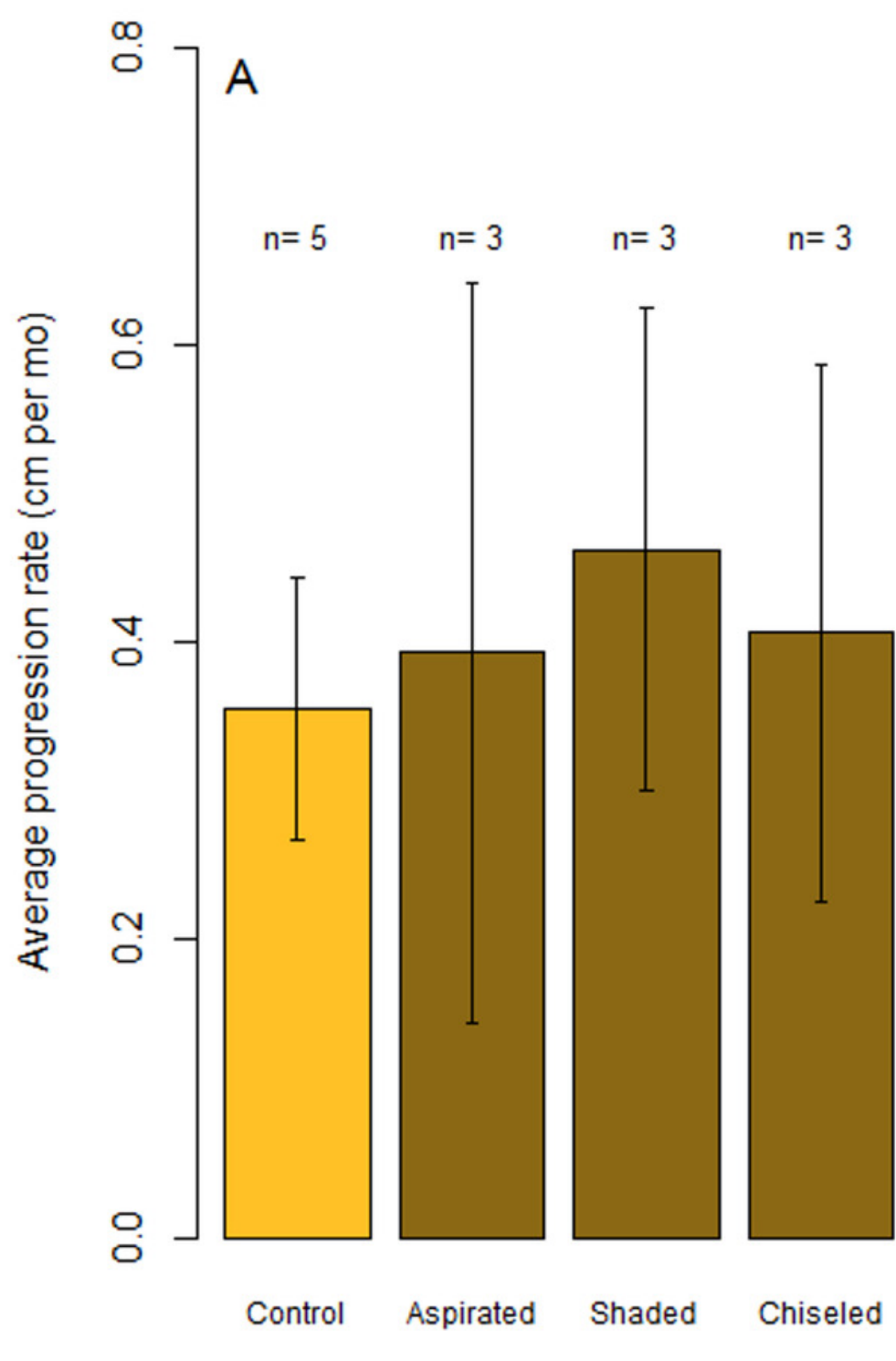

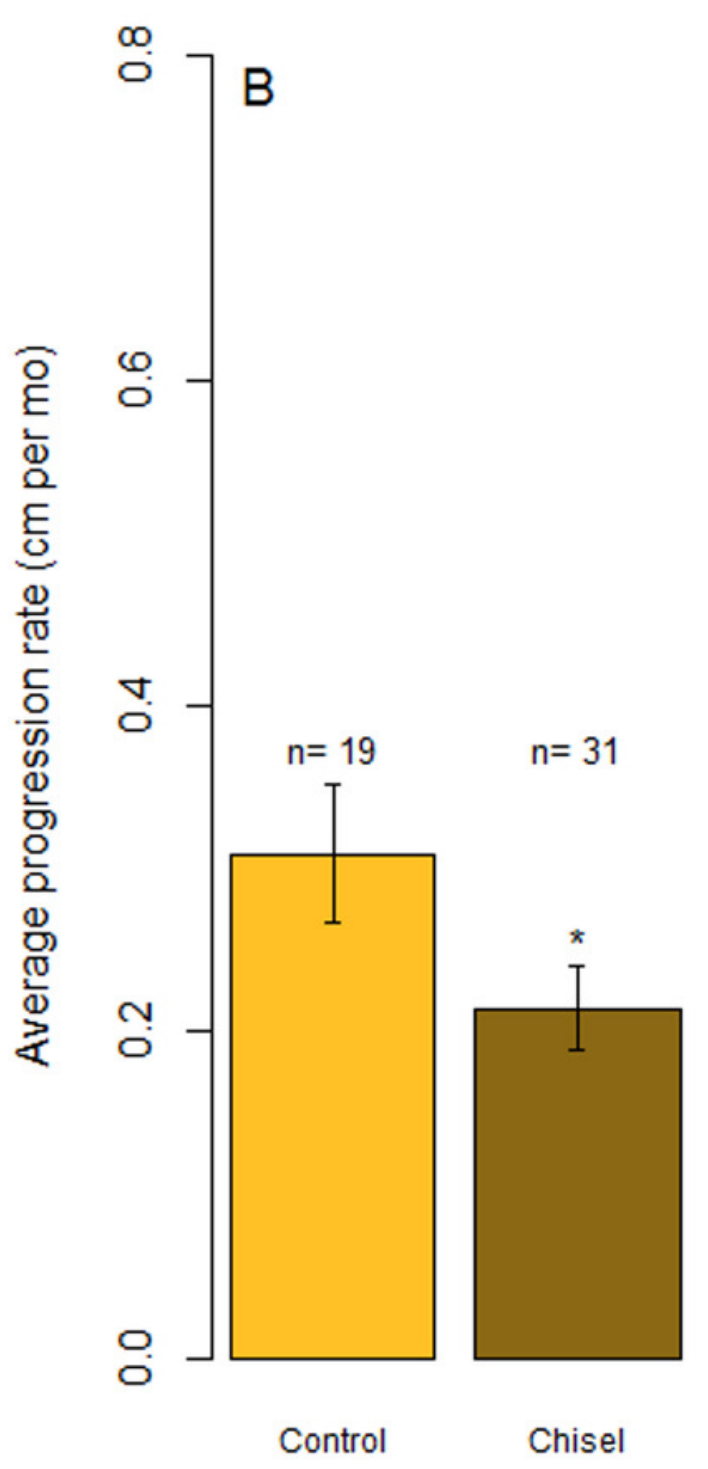

Treatment 


\section{Figure 7}

Results of the chiseling technique.

Time series images of chisel-treated $(A, B, C, F, G, H)$ and control $(D, E, I, J)$ yellow bands on Orbicella faveolata. Arrows indicate the chisel line on each colony. Photo credit: C. J. Randall.
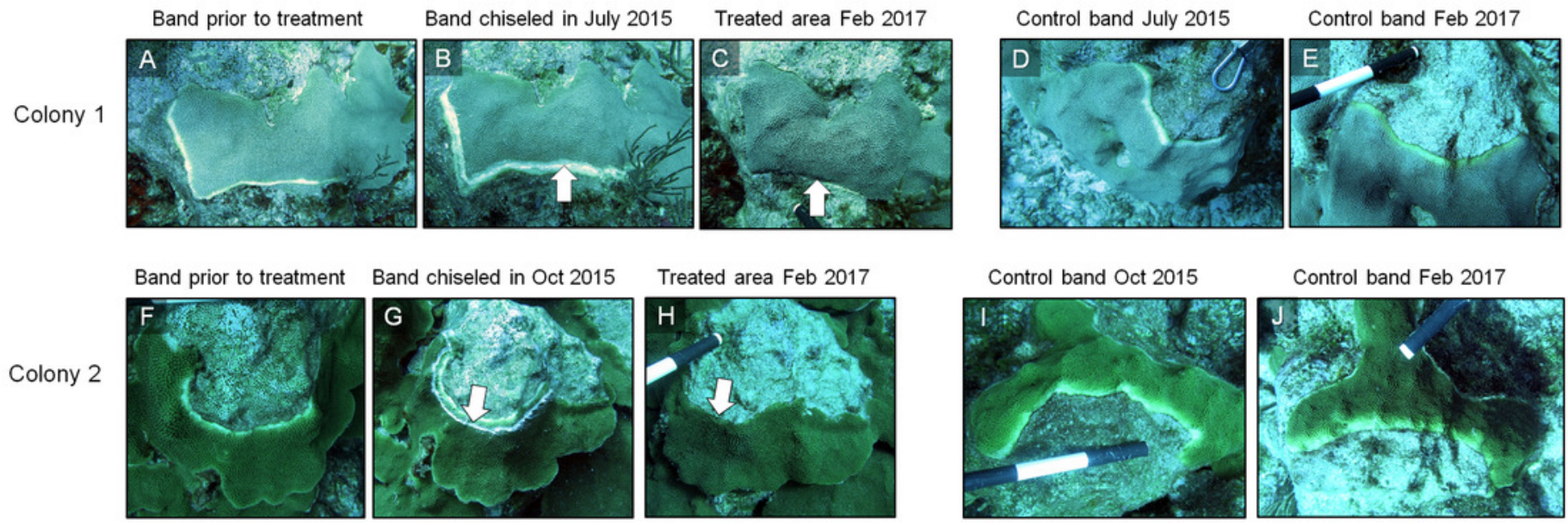

Control band Feb 2017

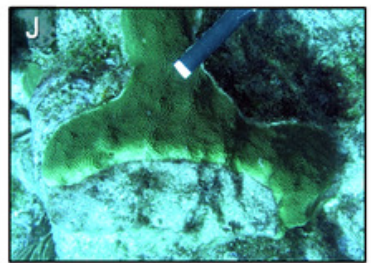




\section{Figure 8 (on next page)}

Health conditions of treated corals through time.

Proportion of all Orbicella faveolata colonies that were classified at each of three health conditions post chiselling, in March 2016 and February 2017. See text for definitions of each health condition. Above each bar, the month of chiselling (2015) and the sample size are indicated. 


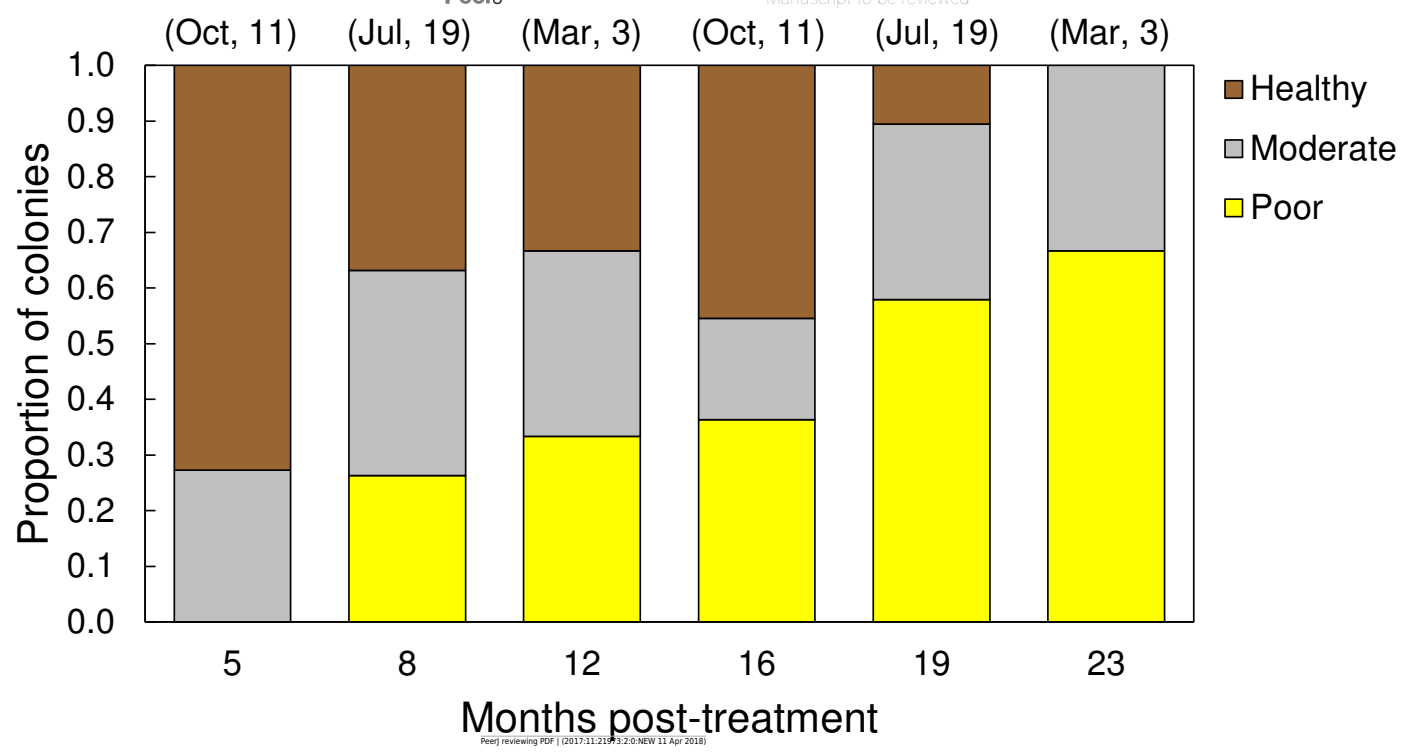




\section{Table $\mathbf{1}$ (on next page)}

Condition of chisel-treated disease lesions.

Conditions of the Caribbean yellow-band disease (CYBD) lesions on Orbicella faveolata that were treated via the chisel method. Corals were treated either in March, July, or October 2015. The condition of all corals was evaluated in March 2016 and again in February 2017. 'Healthy' was defined as a healed tissue margin with no grossly visible signs of CYBD past the chiseled margin. 'Moderate' was defined as a healed tissue margin with no tissue loss but with tissue reconnection to lesions. 'Poor' condition was defined as the presence of grossly visible signs of CYBD with possible tissue loss. 


\begin{tabular}{|c|c|c|c|}
\hline Coral ID & $\begin{array}{c}\text { Original } \\
\text { Chisel Date }\end{array}$ & $\begin{array}{c}\text { Condition } \\
\text { March } \\
2016 \\
\end{array}$ & $\begin{array}{c}\text { Condition } \\
\text { Feb } 2017\end{array}$ \\
\hline $\mathrm{CC} 1$ & March 2015 & Moderate & Poor \\
\hline $\mathrm{CC} 2$ & March 2015 & Poor & Poor \\
\hline $\mathrm{CC} 3$ & March 2015 & Healthy & Moderate \\
\hline 12 & July 2015 & Healthy & Poor \\
\hline $31 \mathrm{~A}$ & July 2015 & Moderate & Moderate \\
\hline $31 \mathrm{~B}$ & July 2015 & Poor & Poor \\
\hline $37 \mathrm{~A}$ & July 2015 & Healthy & Healthy \\
\hline $37 \mathrm{~B}$ & July 2015 & Poor & Poor \\
\hline 41 & July 2015 & Moderate & Poor \\
\hline 51 & July 2015 & Healthy & Moderate \\
\hline 55 & July 2015 & Moderate & Poor \\
\hline 56 & July 2015 & Moderate & Poor \\
\hline 58 & July 2015 & Poor & Poor \\
\hline 59 & July 2015 & Healthy & Poor \\
\hline 60 & July 2015 & Healthy & Healthy \\
\hline 105 & July 2015 & Healthy & Moderate \\
\hline $107 \mathrm{~N}$ & July 2015 & Moderate & Poor \\
\hline 1070 & July 2015 & Poor & Poor \\
\hline 108 & July 2015 & Moderate & Moderate \\
\hline $\mathrm{SC} 1$ & July 2015 & Healthy & Moderate \\
\hline $\mathrm{SC} 2$ & July 2015 & Poor & Poor \\
\hline $\mathrm{SC} 3$ & July 2015 & Moderate & Moderate \\
\hline 122 & October 2015 & Moderate & Healthy \\
\hline 123 & October 2015 & Healthy & Healthy \\
\hline 124 & October 2015 & Moderate & Poor \\
\hline 126 & October 2015 & Healthy & Moderate \\
\hline 127 & October 2015 & Moderate & Poor \\
\hline 128 & October 2015 & Healthy & Poor \\
\hline $129 \mathrm{~A}$ & October 2015 & Healthy & Healthy \\
\hline $129 \mathrm{~B}$ & October 2015 & Healthy & Poor \\
\hline $130 \mathrm{~A}$ & October 2015 & Healthy & Healthy \\
\hline 130B & October 2015 & Healthy & Healthy \\
\hline 131 & October 2015 & Healthy & Moderate \\
\hline \multirow{3}{*}{ Percentage } & Healthy & $48.5 \%$ & $21.2 \%$ \\
\hline & Moderate & $33.3 \%$ & $27.3 \%$ \\
\hline & Poor & $18.2 \%$ & $51.5 \%$ \\
\hline
\end{tabular}

